\title{
Iot-Based Smart Trash Monitoring Using Blynk Application
}

\author{
Widodo \\ Department of Electrical Engineering \\ University of PGRI Adi Buana Surabaya \\ widodo@unipasby.ac.id
}

\author{
Ali Nur Rifky \\ Department of Electrical Engineering \\ University of PGRI Adi Buana Surabaya \\ AliNurRifky@gmail.com
}

\begin{abstract}
Poor waste management and lack of public awareness of environmental hygiene, especially if waste is disposed of in the local trash can, causes garbage to accumulate and emit bad odors which can be a source of disease transmission. The lack of information technology for waste management by janitors can cause slow waste disposal. Based on these problems, it is necessary to equip an automatic trash can with a monitoring function in real time. Added the IOT (Internet of Things) function, which can provide initial information indicating that the trash can is full and can be quickly picked up by the garbage collector. The smart trash can prototype uses an ESP 32 microcontroller as a system control. Servo to control the trash can cover. The output of DF Player is in the form of thanks to people who throw garbage in its place. Ultrasonic sensors can detect human presence and waste volume and send monitoring results in real time as well as notifications to the blynk application as a notification if the trash can is full.
\end{abstract}

Keywords: Waste management, Smart Trash, ESP 32 Microcontroller, Internet Of Things

\section{INTRODUCTION}

Garbage is an unavoidable problem. If left unchecked, it will have an impact on the environment becoming dirty and unhealthy. The impact that will occur on the environment if waste management is not completed effectively and efficiently will result in the environment becoming dirty and unhealthy for the survival of the surrounding environment.
Management of waste management that is not effective either will cause the accumulation of waste and the increasing accumulation of waste will have a detrimental impact, for example the pile of garbage can emit a bad smell and can be a source of disease transmission A simple example of the waste problem is often encountered in the home, school, or office environment where garbage can also accumulate around a full trash can, this can happen due to the high volume of waste generated or the lack of cleaners when controlling the trash can. According to Ali Wafi(2019) the lack of public awareness and concern for environmental cleanliness causes the waste problem to remain a serious problem for the government.

With these problems, an early detection and warning tool is needed about the condition of the volume of the trash can that can send information that the trash can is full so that it can be processed quickly to prevent the accumulation of garbage. In this study, the author will design an IoT (Internet of Thing)-based automatic trash bin monitoring system using the HC-SR04 sensor as a distance detector to determine the volume of waste in the trash, then to give notification or notification that the trash can is full, the notification can be seen on the janitor's cellphone using the blynk application on the android platform.

\section{METHODS}

Tool design includes the design of the physical appearance that will be built as desired. This section consists of mechanical, electrical and software designs that are interconnected to carry out a step-by-step process according to the design. 


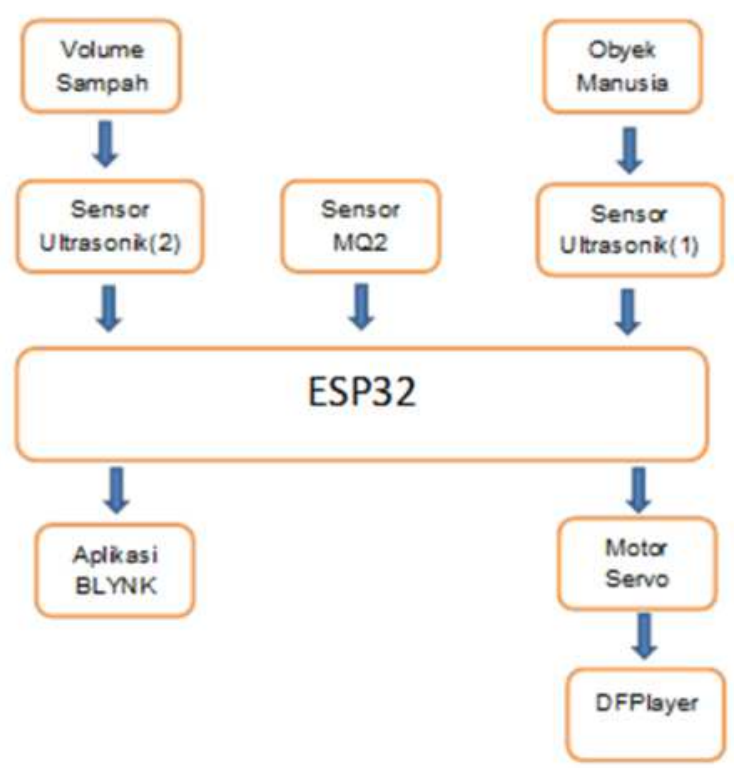

Fig. 1 flow chart

The tool that was built is a smart trash monitoring tool based on the blynk application where the trash can can open itself and when someone has dumped trash in the trash can, the trash can outputs a thank you sound automatically. The height of the trash can and smoke detection can be monitored in real live through the blynk application that has been programmed in the monitoring tool. The following is a schematic drawing of the device circuit.

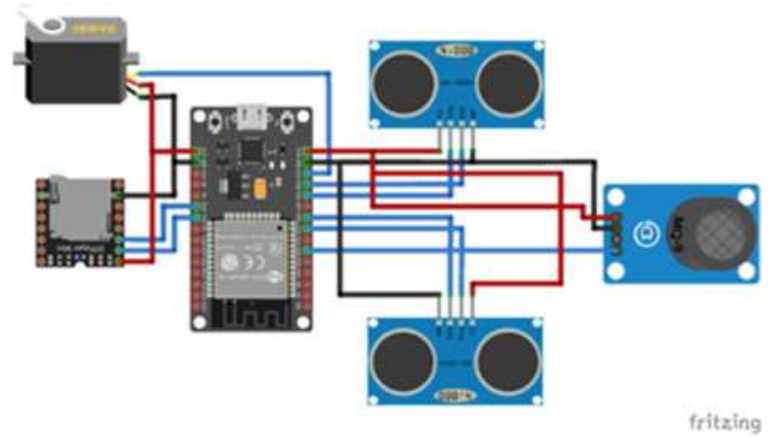

Fig. 2 Schematic design of the tool

The design of the tool in the design of this smart trash monitoring tool uses a plastic trash can which is mechanically regulated by means of the tool and can still function manually as well. The driver application is used to pull the trash can lever so that the trash can opens automatically and the placement of the entire series is under the trash can.
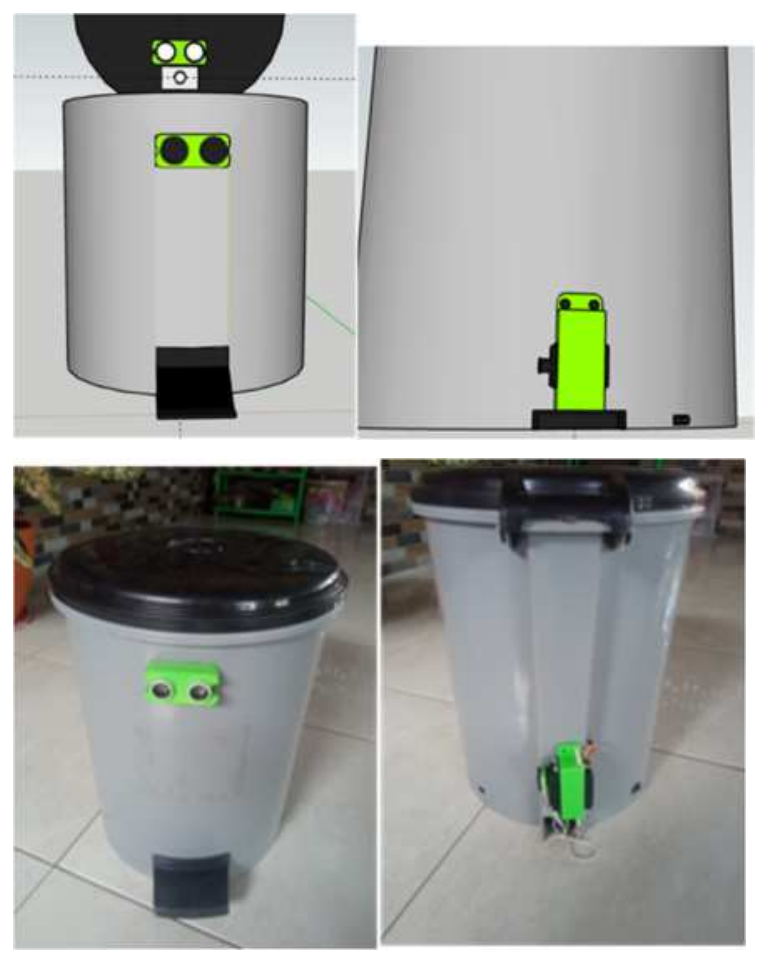

Fig. 3 Design Tool.

For the design of the software on Blynk, it can monitor the height of the garbage and smoke in life, if the trash can is full, the application will provide a notification that will appear on the task bar of the Android mobile phone that has been set in the Blynk application.

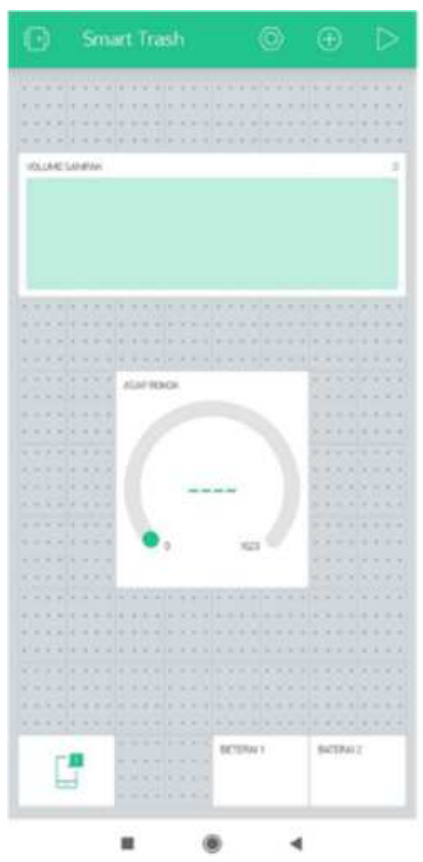

Fig. 4 Blynk Application Design Flowchart. 


\section{BEST}

Journal of Applied Electrical \& Science Technology - University of PGRI Adi Buana Surabaya

p-ISSN 2715-2871

e-ISSN 2714-5247

\section{RESULTS AND DISCUSSION}

The collection and presentation of data is a very important part in making reports or research. Any type of report always uses data in presenting the facts or information contained in the report.

Table 1. Lab Scale Tool Troble Test.

\begin{tabular}{|c|c|c|c|c|c|c|c|c|}
\hline \multirow{2}{*}{ No } & \multirow{2}{*}{$\begin{array}{c}\text { Presentase } \\
\text { Baterai }\end{array}$} & \multicolumn{6}{|c|}{ Tahap Percobaan Pengujian Alat } & $\begin{array}{c}\text { Rata- Rata } \\
\text { Hasil } \\
\text { Keberhasilan }\end{array}$ \\
\cline { 3 - 7 } & 1 & \multicolumn{2}{|c|}{2} & \multicolumn{2}{|c|}{3} & \multicolumn{2}{|c|}{4} & \multicolumn{2}{|c|}{5} & Kerhil \\
\hline 1 & $100 \%$ & Berhasil & Berhasil & Berhasil & Berhasil & Berhasil & $100 \%$ Berhasil \\
\hline 2 & $80 \%$ & Berhasil & Berhasil & Berhasil & Berhasil & Berhasil & $100 \%$ Berhasil \\
\hline 3 & $60 \%$ & Berhasil & Berhasil & Berhasil & Berhasil & Berhasil & $100 \%$ Berhasil \\
\hline 4 & $40 \%$ & Berhasil & Berhasil & Berhasil & Gagal & Gagal & $60 \%$ Berhasil \\
\hline 5 & $20 \%$ & Gagal & Berhasil & Berhasil & Gagal & Gagal & $40 \%$ Berhasil \\
\hline
\end{tabular}

The data taken in the laboratory-scale tool troble test is the error of the Smart Trash tool when working. As for here the sample error is taken
Tool testing aims to find out whether this smart trash monitoring tool works efficiently. In the table below, look for the work error of the tool in a lab test withdata retrieval gradually according to the percentage of battery.

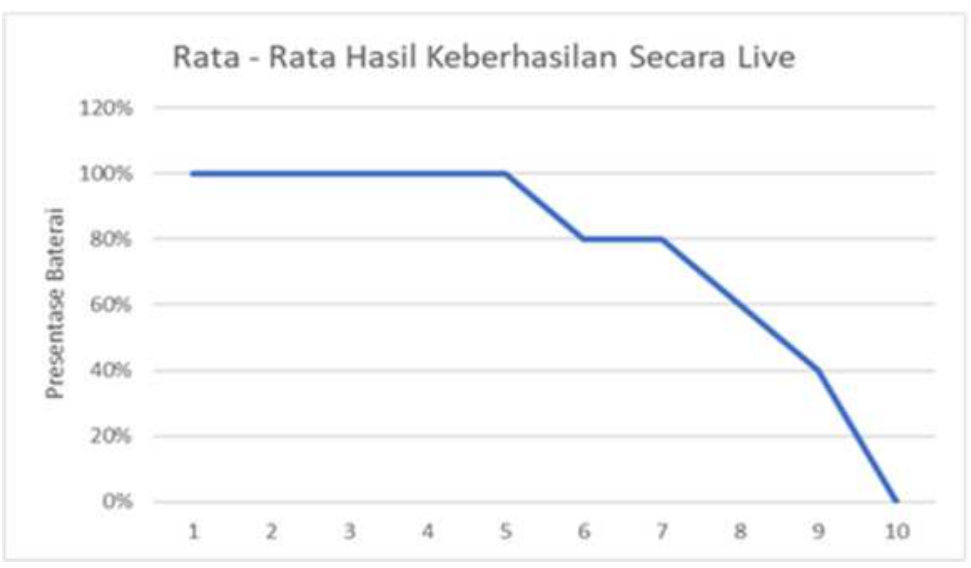

Fig.5 Lab error measurement graph

Then a real live test was carried out in a kindergarten school by producing the following data.

\begin{tabular}{c|c|c|c|c|c|c|}
\hline \multirow{2}{*}{$\begin{array}{c}\text { Presentase } \\
\text { Baterai }\end{array}$} & \multicolumn{5}{|c|}{ Tahap Percobaan Pengujian alat } & \multirow{2}{*}{$\begin{array}{c}\text { Rata - Rata } \\
\text { Hasil } \\
\end{array}$} \\
\cline { 2 - 6 } & 1 & 2 & 3 & 4 & 5 & Keberhasilan \\
\hline $100 \%$ & Berhasil & Berhasil & Berhasil & Berhasil & Berhasil & $100 \%$ Berhasil \\
\hline $90 \%$ & Berhasil & Berhasil & Berhasil & Berhasil & Berhasil & $100 \%$ Berhasil \\
\hline $80 \%$ & Berhasil & Berhasil & Berhasil & Berhasil & Berhasil & $100 \%$ Berhasil \\
\hline $70 \%$ & Berhasil & Berhasil & Berhasil & Berhasil & Berhasil & $100 \%$ Berhasil \\
\hline $60 \%$ & Berhasil & Berhasil & Berhasil & Berhasil & Berhasil & $100 \%$ Berhasil \\
\hline $50 \%$ & Eror & Berhasil & Berhasil & Berhasil & Berhasil & $80 \%$ Berhasil \\
\hline $40 \%$ & Berhasil & Berhasil & Eror & Berhasil & Berhasil & $80 \%$ Berhasil \\
\hline $30 \%$ & Eror & Berhasil & Berhasil & Berhasil & Eror & $60 \%$ Berhasil \\
\hline $20 \%$ & Eror & Berhasil & Eror & Eror & Berhasil & $40 \%$ Berhasil \\
\hline $10 \%$ & Eror & Eror & Eror & Eror & Eror & $0 \%$ Berhasil \\
\hline
\end{tabular}

Table 2. Live Tool Trouble Test 
The data taken in the live tool troble test is the error of the Smart Trash tool while working. Implementation of Smart Trash Monitoring in a Kindergarten School Institution in Cangkringsari Village, Sukodono District. As for here the sample error is taken from several conditions, namely according to the percentage of the battery that supplies the tool when it is working. The following data is generated.

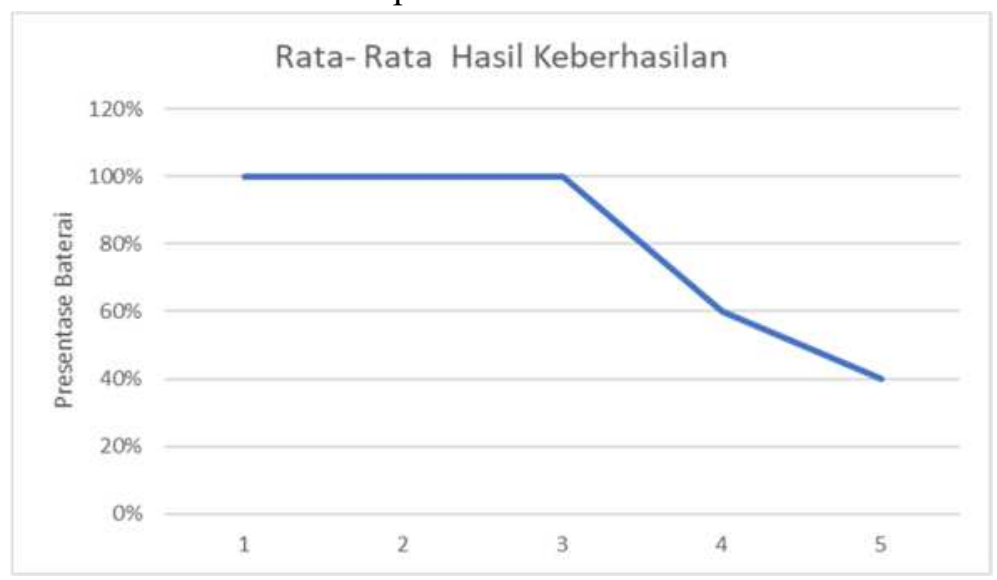

Fig.6 Live error measurement graph

The author's success when making IoTbased smart trash monitoring using the Blynk application, in terms of how it works and the usefulness of the tool is $90 \%$, all photo evidence is listed as follows.

The advantages and disadvantages of the IoT-Based Smart Trash Monitoring tool using the Blynk Application are as follows:

\section{Advantages}

1. Trash can be placed anywhere (Portable)

2. The tool can be used as an early childhood education, so that they can dispose of garbage in its place

3. The height of the garbage can be found using Android which can be monitored even remotely

\section{Deficiency}

1. Reading the height of the garbage is still not efficient because there is still a lot of free space

2. The trash can only applies to dry plastic waste and paper waste, not to wet waste

3. Battery life to run Smart Trash must be recharged every time

4. Applications that are still limited can only be accessed on 1 cellphone only

\section{CONCLUSION}

From a series of research, testing and analysis of IoT-Based Smart Trash Monitoring Using the Blynk Application, it can be concluded as follows:

1. Smart Trash is very useful when implemented for early childhood, so they can be enthusiastic about throwing garbage in its place

2. Ultrasonic sensor can give a quick response when there is an object blocking it

3. Ultrasonic sensor that functions to measure the height of the trash, placed in the middle of the trash can cover to avoid garbage piling up on the side only

4. The power consumption of the tool is low, so 3pcs 185603.7 volt batteries can be used for approximately 12 hours

5. The speed of sending garbage height data to the android application is quite fast, depending on network conditions at its location2. The rotary encoder data is processed using a circular formula divided by the rotary step and multiplied by the rotation direction of the rotary encoder. 


\section{REFERENCES}

[1] Hardyanto, R. Hafid. "Internet of Things Concepts in Web-Based Learning." Journal of Informatics Dynamics 6.1 (2017): 87-97

[2] Sohor, Suherman, and Yuda Irawan. "Design Automatic Trash Can Using Microcontroller And Ultrasonic Sensor With Telegram Notifications." Journal of Computer Science 9.2 (2020): 154-160

[3] Rufaidah, RA, Darlis, D., \& Hafidudin. (2014). Design and Implementation of Microcontroller Based Garbage Pile Monitoring System With Social Media Notifications

[4] Rochman, HA, Primananda, R., \& Nurwasito, H. (2017). Microcontroller Based Control System Using MQTT Protocol on Smarthome. Journal of Information Technology and Computer Science Development, 1(6). Retrieved from http://j-ptiik.ub.ac.id/index.php/jptiik/article/view/132

[5] Raharjo, TAAP, Akbar, SR, \& Primananda, R. (2018). Volume and Waste Gas Monitoring System Using Real Time Operating System (RTOS) Method. Journal of Information Technology and Computer Science Development, 2(11), 5651-5658

[6] Rochman, Sagita, and Bagus Ilham Yunianto. "Prototype Automatic Lights Control System In The Mosque Area Based On Arduino Nano." BEST: Journal of Applied Electrical, Science, \& Technology 1.1 (2019): 32-35.

[7] Rochman, Sagita, and M. Nushron Ali Mukhtar. "Classification Of The Quality Of Honey Using The Spectrofotometer And Machine Learning System Based On Single Board Computer." Tibuana 2.01 (2019): 45-49.

[8] Sukarjadi, Sukarjadi, et al. "Design and Manufacture of Smart Trash Bin at Maarif Hasyim Latif University." Teknika: Engineering and Sains Journal 1.2 (2017): 101-110

[9] Zulfikri, AA, Perdana, D., \& Bisono, G. (2018). Design and Analysis of Trash Monitoring System Prototype Based On
Internet of Things (IoT) Using MQTT Protocol. Infotel Journal. https://doi.org/https://.doi.org/10.20895/inf otel. vol issue.page 